\title{
USE OF MARKERS TO DETERMINE THE ILEAL DIGESTIBILITY OF AMINO ACIDS FOR SWINE
}

\author{
Uso de indicadores para determinar a digestibilidade \\ ileal de aminoácidos para suínos
}

\author{
Paulo Cesar Pozza ${ }^{1}$, Paulo Cezar Gomes², Magali Soares Santos Pozza ${ }^{3}$, Ricardo Vianna Nunes ${ }^{3}$, \\ Rony Antônio Ferreira ${ }^{4}$, Ramalho José Barbosa Rodrigueiro ${ }^{5}$
}

\begin{abstract}
Many markers can be used in digestibility assays for swine, but needs to be evaluated before its use. An assay was carried out with the objective of measuring the coefficients of ileal apparent (CIAD) and standardized digestibility (CISD) of amino acids in meat and bone meal for swine using different markers. Eight crossbred barrows were equipped with T-cannulas in the distal ileum. Four animals received a free protein diet and another four received a diet containing meat and bone meal as the only protein source in the diet. The treatments consisted in evaluating the chromic oxide, acid-insoluble ash naturally occurring in the diet, cellulose and lignin as markers to determine the apparent and standardized digestibility of the amino acids contained in the meat and bone meal. All data were submitted to analysis of variance and means were compared using the Tukey test, with a significance of 5\%. The CIAD, obtained using chromic oxide as external marker, were lower $(\mathrm{P}<0.05)$ than those obtained when acid insoluble ash, lignin and cellulose were used as markers, observing differences for all the amino acids evaluated. Similarly, the CISD from all the studied amino acids were lower $(\mathrm{P}<0.05)$ when the chromic oxide was used for determining the indigestibility factor. It is concluded that chromic oxide used as a external marker, to determine the coefficients of apparent and standardized ileal digestibility of the amino acids of the meat and bone meal, is most appropriate than the acid insoluble ash naturally occurring in diets, lignin and cellulose.
\end{abstract}

Index terms: Acid-insoluble ash, cellulose, chromic oxide, lignin, simple T- cannula.

\section{RESUMO}

Muitos indicadores podem ser utilizados em ensaios de digestibilidade para suínos, mas precisam ser avaliados antes de serem utilizados. O experimento foi realizado com o objetivo de determinar os coeficientes de digestibilidade ileal aparentes (CDIA) e estandardizados (CDIE) dos aminoácidos da farinha de carne e ossos, para suínos, utilizando diferentes indicadores. Oito suínos, machos castrados, foram submetidos à cirurgia para aimplantação de cânulas T simples, no íleo distal. Quatro animais receberam uma dieta isenta de proteína e outros quatro uma dieta contendo farinha de carne e ossos como única fonte protéica na dieta. Os tratamentos consistiram em avaliar o óxido crómico, cinza insolúvel em ácido naturalmente contido na dieta, celulose e lignina como indicadores para determinar os CDIA e CDIE dos aminoácidos da farinha de carne e ossos. Os dados foram submetidos a análise de variância e as médias foram comparadas pelo teste de Tukey, ao nível de 5\% de significância. Os CDIA, obtidos usando o óxido crômico como indicador externo, foram menores $(\mathrm{P}<0,05)$ em relação aos obtidos utilizando cinza insolúvel em ácido, lignina e celulose como indicadores, observando-se diferenças para todos os aminoácidos avaliados. O CDIE de todos os aminoácidos estudados foram menores $(\mathrm{P}<0,05)$ quando o óxido crômico foi utilizado para a determinação do fator de indigestibilidade. Conclui-se que o óxido de cromo utilizado como indicador externo, para determinar os coeficientes de digestibilidade ileal aparente e standarizado dos aminoácidos da farinha de carne e ossos, é mais apropriado do que a lignina, celulose e a cinza insolúvel em ácido naturalmente encontrada na dieta.

Termos para indexação: Cinza insolúvel em ácido, celulose, óxido crômico, lignina, cânula T simples.

(Received in february 1,2013 and approved in april 1, 2013)

\section{INTRODUCTION}

The use of digestible amino acid in diets formulation for swine is a necessary practice to achieve the maximum animal's performance in the different stages of production. The ileal digestibility of amino acids can be expressed in terms of apparent, true or standardized digestibility, where the latter considers the basal endogenous losses, providing higher values compared to the apparent ileal digestibility. To determine the ileal digestibility of amino acids for swine is necessary to know the quantity of amino acids

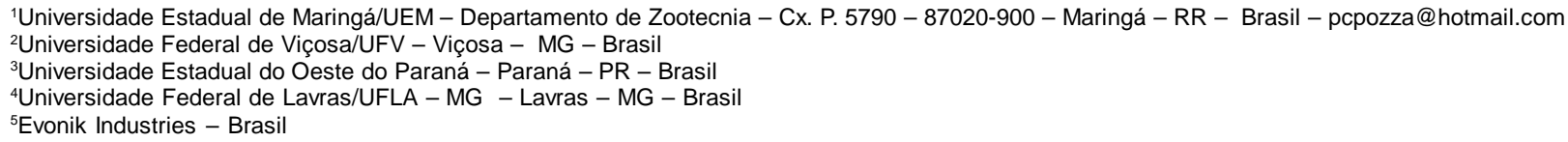


contained in the diet and digesta, as their amounts consumed and excreted, being necessary the estimative of these amounts when working on partial collection. In this way, the use of markers is necessary to determine the ileal digestibility of amino acids for swine, using the amount of marker contained in the diet and digesta (SAKOMURA; ROSTAGNO, 2007) and, according to Berchielli, Oliveira and Garcia (2005), marker is the term used to refer to materials used in qualitative or quantitative estimation of nutritional or physiological phenomena related to digestion.

In the same way, Zhang et al. (2002) reported that inert markers are frequently employed in digestibility studies, providing means of calculating the nutrient digestibility when the complete collection of digesta from a known quantity of feed consumed can not be undertaken.

Markers are considered as inert substances that are not absorbed, thereby, as amino acids and other nutrients are absorbed in the small intestine the indicator concentration in the digesta tends to increase, compared with its concentration in the evaluated diet. These markers can be divided into internal, represented by indigestible substances present in the diet, or externals, when they are intentionally added to the diet.

Many substances can be used and among the external markers the chromic oxide $\left(\mathrm{Cr}_{2} \mathrm{O}_{3}\right)$ is the most commonly used, but other markers have been studied as an alternative. Among these the acid insoluble ash, proposed by McArthy, Aherne and Okai (1974), is an alternative to the use of chromic oxide. The internal markers show advantages once they are already present in the food and, generally, remain distributed in the digesta during the digestion and excretion processes (PIAGGIO et al., 1991), and may be represented by a fraction of the cell wall.

In addition to the acid insoluble ash, others substances that do not meet all the requirements are discussed as possible markers and the cellulose could be considered and, according to Liebler, Pohlenz and Whipp (1992), the cellulose digestion does not occur in the small gut of pigs, but depends on the microbial fermentation which occurs in the large gut. Thus, due to the digesta collection be carried out at the end of the ileum, the cellulose could be studied as marker. Furthermore, in the studies carried out to determine the ileal digestibility of amino acids in feeds for swine, a fiber source is used in the diet, such as rice hulls and cellulose sources that are purposefully added to experimental diets.
In the same way, it is well known that lignin is virtually indigestible in the digestive tract of the swine (JAGGER et al, 1992), and could be studied as a marker, because some fiber sources used in experimental diets, to determine the ileal digestibility of amino acids, shows an amount of lignin in the composition.

As described, many substances can be used as markers in digestibility trials, but Zeoula et al. (2000) reported that the search for ideal markers is one of the subjects of great interest in finding techniques that facilitate the studies on the animal nutrition.

The objective of this study was to evaluate the apparent and standardized ileal digestibility of amino acids of meat and bone meal for swine, using the chromic oxide, acid insoluble ash naturally occurring in the diets, cellulose and lignin as markers.

\section{MATERIALS AND METHODS}

The experiment was carried out in the swine farm of the Viçosa Federal University - Brazil. Eight crossbreed barrows (Landrace $\mathrm{x}$ Large White) were submitted to the surgery for simple "T" cannula implantation, and these cannulas were produced from stainless steel. Anesthesia was maintained with halothane and oxygen-nitrogen mixture in a closed circuit system administered through nasal intubation.

Following surgery, the barrows were moved to recovery pens outside the surgery room and observed for $3 \mathrm{~h}$ after surgery or until fully awake. The animals underwent a period of 20 days for recovery. During this period the animals were individually housed in raised pens, equipped with plastic floors, wired walls, semi-automatic feeders and nipple drinkers.

After the recovery period, the barrows, averaging $50.92 \pm 4.08 \mathrm{~kg}$ initial weight, were submitted to the experimental diets, staying all the experimental period in the same buildings where were housed during the recovery period.

Within the building was used a thermometer to measure the minimum and maximum temperature, which was carried out twice daily during the experimental period. Four animals received a free-protein diet and another four received the diet containing the meat and bone meal as the only protein source (Table 1). The free-protein diet was used to determine the endogenous amino acid losses.

The treatments consisted in evaluating the markers (chromic oxide, acid insoluble ash naturally occurring in the diet, cellulose and lignin) to determine the apparent 
and standardized digestibility of the amino acids contained in the meat and bone meal.

The experimental diets contained $0.5 \%$ chromic oxide $\left(\mathrm{Cr}_{2} \mathrm{O}_{3}\right)$, used as external marker to determine digestibility. The rice hulls, used as fiber source, were separated from the broken rice grains, of the still remaining within the hulls and of the impurities contained in the material by means of fan. The amino acids contained in the rice hulls (Table 2) were considered totally indigestible, and subtracted from the values of endogenous losses.

Table 1 - Composition of the free-protein $\operatorname{diet}$ (FPD) and diet containing meat and bone meal (MBM).

\begin{tabular}{|c|c|c|}
\hline Ingredients (\%) & FPD & MBM \\
\hline Meat and bone meal ${ }^{1 /}$ & - & 21.92 \\
\hline Rice hull ${ }^{2 /}$ & 5.24 & 4.55 \\
\hline Sugar $^{3 /}$ & 10.00 & 10.00 \\
\hline Corn starch ${ }^{3 /}$ & 79.78 & 61.52 \\
\hline Soybean oil ${ }^{3 /}$ & 1.00 & 1.00 \\
\hline Dicalcium phosphate & 2.97 & - \\
\hline Sodium chloride & 0.35 & 0.35 \\
\hline Micro minerals ${ }^{4 /}$ & 0.10 & 0.10 \\
\hline Vitamins ${ }^{5 /}$ & 0.05 & 0.05 \\
\hline Antioxidant ${ }^{6 /}$ & 0.01 & 0.01 \\
\hline Chromic oxide & 0.50 & 0.50 \\
\hline \multicolumn{3}{|l|}{ Composition } \\
\hline Dry matter $(\%)^{\frac{7}{}}$ & 85.34 & 88.93 \\
\hline Crude protein $(\%)^{\frac{7}{}}$ & 0.48 & 11.50 \\
\hline Metabolizable energy $(\mathrm{kcal} / \mathrm{kg}$ ) & 3265 & 3194 \\
\hline Calcium $(\%)^{\frac{7}{}}$ & 0.68 & 1.99 \\
\hline Total phosphorus $(\%)^{\frac{7}{}}$ & 0.51 & 1.24 \\
\hline Crude fiber $(\%)^{7 /}$ & 2.00 & 2.00 \\
\hline
\end{tabular}

1/ Metabolizable energy determined by Pozza et al. (2008).

2/ Metabolizable energy obtained from Empresa Brasileira de Pesquisa Agropecuária-Embrapa (1990).

3/ Metabolizable energy obtained from Rostagno et al. (2005).

4/ Content/kg: Iron, $100 \mathrm{~g}$; cooper, $10 \mathrm{~g}$; cobalt, $1 \mathrm{~g}$; manganese, $40 \mathrm{~g}$; zinco, $100 \mathrm{~g}$; iodine, $1.5 \mathrm{~g}$; e q.s.p. vehicle $500 \mathrm{~g}$.

5/ Content/kg: vit. A, 10.000.000 U.I.; vit $\mathrm{D}_{3}, 1.500 .000$ U.I.; vit. E, 30.000 U.I.; vit $\mathrm{B}_{1}-2.0 \mathrm{~g}$; vit $\mathrm{B}_{2}-5.0 \mathrm{~g}$; vit. $\mathrm{B}_{6}-3.0 \mathrm{~g}$; vit $\mathrm{B}_{12}-30.000 \mathrm{mcg}$; ácido nicotínico $30.000 \mathrm{mcg}$; pantothenic acid, $12.000 \mathrm{mcg}$; vit. $\mathrm{K}_{3}, 2.000 \mathrm{mg}$; folic acid, $800 \mathrm{mg}$; biotin, $100 \mathrm{mg}$; selenium $300 \mathrm{mg}$; e veículo q.s.p - $1.000 \mathrm{~g}$.

6/ BHT.

7/ Determined in the Laboratory of Animal Nutrition - Viçosa Federal University.
Table 2 - Amino acid composition of the rice hulls and meat and bone meal as fed basis.

\begin{tabular}{lcc}
\hline Amino acids $(\%)^{1}$ & Rice Hulls & Meat and Bone Meal \\
\hline Lysine & 0.069 & 2.362 \\
Methionine & 0.021 & 0.612 \\
Threonine & 0.070 & 1.574 \\
Arginine & 0.056 & 3.722 \\
Valine & 0.091 & 1.906 \\
Isoleucine & 0.050 & 1.241 \\
Leucine & 0.110 & 2.763 \\
Histidine & 0.028 & 0.897 \\
Phenylalanine & 0.066 & 1.564 \\
Cystine & 0.023 & 0.380 \\
Alanine & 0.105 & 3.866 \\
Aspartic acid & 0.139 & 3.506 \\
Glutamic acid & 0.180 & 6.038 \\
Glycine & 0.083 & 7.393 \\
Serine & 0.071 & 1.892 \\
Tyrosine & 0.017 & 0.792 \\
\hline - Analyss
\end{tabular}

1 - Analyses carried out in Ajinomoto Industries by HPLC method.

The amount of feed provided per pig per meal during the experimental period was calculated on the basis of metabolic body weight $\left(\mathrm{BW}^{0,75}\right)$. The barrows were fed at 07:00 $\mathrm{h}$ and 19:00 $\mathrm{h}$ each day. The experimental diets were mixed with water $(1: 1 ; \mathrm{w} / \mathrm{v})$ prior to feeding and fresh water was freely available between meals. The barrows consumed their ration within 20 minutes of feeding.

Following the recovery period, barrows were fed on the experimental diets. After five days of adaptation to the experimental diets the digesta collection was performed. Collection of ileal digesta started one hour after the morning feeding on day 6 and lasted for $24 \mathrm{~h}$., being realized in 3 hours intervals. The cannulas were opened and a soft polyetilene bag was attached to the barrel of each cannula. The bags were replaced at each collection of ileal digesta. Samples were frozen immediately at $-5^{\circ} \mathrm{C}$ and stored for future analyses.

At the experiment conclusion, samples were thawed, mixed within animal and diet, and a sub-sample was taken for chemical analysis. All digesta samples were lyophilized and finely ground prior to chemical analysis. Dry matter (DM) was analyzed in digesta and diets according to the standard procedures of Association Of Official AnalyticalAoac (2005). 
Amino acids were analyzed in the Animal Nutrition Laboratory of Viçosa Federal University and in Ajinomoto Industries, using a HPLC analyzer.

Chromium content of diets and digesta samples were determined using spectrophotometry as described by Fenton and Fenton (1979). In the same samples were determined, in the Animal Nutrition Laboratory of UNIOESTE, the acid-insoluble ash content according to the description provided by McArthy, Aherne and Okai (1974), lignin and cellulose was determined according to Silva and Queiroz (2004).

To calculate the ileal digestibility of amino acids were used the levels of chromium, acid insoluble ash, lignin and cellulose in the diets and swine digesta, by calculating the indigestibility factor $-\mathrm{FI}=(\%$ diet marker $) /(\%$ digesta marker), still using the formulas described by Sakomura and Rostagno (2007) to determine the coefficients of apparent and standardized ileal digestibility of amino acids contained in meat and bone meal.

As statistical procedure was used the variance analysis (SAS, 2001) and in case of a significant treatment effect the statistical reliability of differences between treatments (digestive markers) was verified by the Tukey's test (SAS, 2001).

\section{RESULTS AND DISCUSSION}

The barrows, fitted with the simple "T" cannula, stayed healthy throughout the experiment and readily consumed their diets, and the maximum and minimum temperatures registered during the digestibility trial were $25.69 \pm 1.18$ and $21.08 \pm 1.32^{\circ} \mathrm{C}$, respectively.

A comparison of the coefficients of apparent ileal digestibility of amino acids using chromic oxide, acid insoluble ash, lignin and cellulose as markers is presented in table 3 . The results obtained using chromic oxide as external marker were significantly lower $(\mathrm{P}<0.05)$ than those obtained from acid insoluble ash, lignin and cellulose, observing differences for all the amino acids evaluated. In the present experiment, there were no differences in the coefficients of apparent ileal digestibility determined using acid-insoluble ash, cellulose or lignin as digestive markers.

When considered individually, the coefficient of apparent ileal digestibility of lysine, obtained by using chromic oxide as marker is similar to that of 74.9 and $74.0 \%$ proposed by Itcf and Eurolisine (1995) and National Research Council-Nrc (1998) for meat and bone meals with 50.70 and $51.50 \%$ of crude protein, respectively. On the other hand, the coefficients of apparent digestibility obtained for methionine and threonine were higher than those of $78.70 \%$ and $72.30 \%$ presented by Itcf and
Eurolysine (1995), respectively. In the same way, the coefficients obtained for the methionine and threonine were higher than $79.00 \%$ and 70.00 presented by the NRC (1998) for the same protein group of meat and bone meal.

The results obtained for the coefficients of apparent ileal digestibility may be explained by a better recovery of chromic oxide in the digesta, also observed by Kavanagh et al. (2001), in comparison with other evaluated components which in turn were not added in the diet (acid insoluble ash), or were added in the form of rice hull (cellulose and lignin), which may have resulted in inconsistence in the recovery of these compounds in the digesta.

However, Zhang et al. (2000) reported that apparent ileal amino acid digestibility was similar when acid-insoluble ash and chromic oxide as digestive markers were used, but in this study the acid-insoluble ash was not included in the diets as external marker, what may explain the differences obtained for these markers (Table 3 ).

The coefficients of standardized ileal digestibility of amino acids using chromic oxide, acid insoluble ash, lignin and cellulose, as markers are presented in Table 4. The coefficients of standardized ileal digestibility from all the studied amino acids were lower $(\mathrm{P}<0.05)$ when the chromic oxide was used in determining the indigestibility factor.

The coefficient obtained for lysine (81.87\%) using the acid insoluble ash is closer to the $78.99 \%$ proposed by Rostagno et al. (2011) for meat and bone meal with 50.36\% of crude protein, compared to values obtained with the chromic oxide (76.08), cellulose $(85.45 \%)$ and lignin (86.23\%). Moreover, NRC (1998) proposes for meat and bone meal a true digestibility of $80.00 \%$ for lysine, approaching the value obtained with the use of acid insoluble ash, as a naturally occurring marker in the experimental diets.

The NRC (1998) presents coefficients of true ileal digestibility for meat and bone meal from 80.00 and $83.00 \%$ for threonine and methionine, respectively, being more consistent with the values obtained with chromic oxide as a marker, which were 83.07 for threonine and $86.39 \%$ for methionine. In the same way, the coefficients obtained for threonine and methionine, when using chromic oxide, are closer to that proposed by Rostagno et al. (2011) for meat and bone meal compared with the others evaluated markers.

Nowadays the branched chain amino acids are very important in formulating diets for swine, and the coefficients of standardized ileal digestibility obtained for these amino acids (Table 4) are closer to that presented by Rostagno et al. (2011), when the chromic oxide was used as external marker. 
Table 3 - Coefficients of apparent ileal digestibility of amino acids from meat and bone meal using chromic oxide $\left(\mathrm{Cr}_{2} \mathrm{O}_{3}\right)$, acid insoluble ash (AIA), cellulose and lignin as markers.

\begin{tabular}{|c|c|c|c|c|c|}
\hline Amino Acids & $\mathrm{Cr}_{2} \mathrm{O}_{3}$ & AIA & Cellulose & Lignin & $\mathrm{CV}(\%)$ \\
\hline Lysine & $74.80^{\mathrm{b}}$ & $80.89^{\mathrm{a}}$ & $84.17^{\mathrm{a}}$ & $84.87^{\mathrm{a}}$ & 2.84 \\
\hline Methionine & $85.46^{\mathrm{b}}$ & $89.04^{\mathrm{a}}$ & $90.82^{\mathrm{a}}$ & $91.46^{\mathrm{a}}$ & 1.29 \\
\hline Threonine & $81.19^{\mathrm{b}}$ & $85.81^{\mathrm{a}}$ & $88.14^{\mathrm{a}}$ & $88.91^{\mathrm{a}}$ & 1.73 \\
\hline Arginine & $88.29^{\mathrm{b}}$ & $91.15^{\mathrm{a}}$ & $92.62^{\mathrm{a}}$ & $93.07^{\mathrm{a}}$ & 1.02 \\
\hline Valine & $82.35^{\mathrm{b}}$ & $86.67^{\mathrm{a}}$ & $88.88^{\mathrm{a}}$ & $89.56^{\mathrm{a}}$ & 1.62 \\
\hline Isoleucine & $81.79^{\mathrm{b}}$ & $86.23^{\mathrm{a}}$ & $88.53^{\mathrm{a}}$ & $89.21^{\mathrm{a}}$ & 1.69 \\
\hline Leucine & $83.57^{\mathrm{b}}$ & $87.60^{\mathrm{a}}$ & $89.64^{\mathrm{a}}$ & $90.30^{\mathrm{a}}$ & 1.48 \\
\hline Histidine & $87.49^{\mathrm{b}}$ & $90.55^{\mathrm{a}}$ & $92.11^{\mathrm{a}}$ & $92.61^{\mathrm{a}}$ & 1.09 \\
\hline Phenylalanine & $84.72^{\mathrm{b}}$ & $88.47^{\mathrm{a}}$ & $90.37^{\mathrm{a}}$ & $90.98^{\mathrm{a}}$ & 1.36 \\
\hline Cystine & $47.96^{\mathrm{b}}$ & $60.68^{\mathrm{a}}$ & $67.21^{\mathrm{a}}$ & $69.18^{\mathrm{a}}$ & 6.79 \\
\hline Alanine & $88.31^{\mathrm{b}}$ & $91.19^{\mathrm{a}}$ & $92.62^{\mathrm{a}}$ & $93.15^{\mathrm{a}}$ & 1.02 \\
\hline Aspartic acid & $81.73^{\mathrm{b}}$ & $86.20^{\mathrm{a}}$ & $88.48^{\mathrm{a}}$ & $89.20^{\mathrm{a}}$ & 1.67 \\
\hline Glutamic acid & $85.22^{\mathrm{b}}$ & $88.85^{\mathrm{a}}$ & $90.68^{\mathrm{a}}$ & $91.29^{\mathrm{a}}$ & 1.31 \\
\hline Glycine & $92.07^{\mathrm{b}}$ & $94.04^{\mathrm{a}}$ & $94.98^{\mathrm{a}}$ & $95.39^{\mathrm{a}}$ & 0.73 \\
\hline Serine & $81.80^{\mathrm{b}}$ & $86.26^{\mathrm{a}}$ & $88.52^{\mathrm{a}}$ & $89.25^{\mathrm{a}}$ & 1.67 \\
\hline Tyrosine & $78.79^{\mathrm{b}}$ & $83.96^{\mathrm{a}}$ & $86.64^{\mathrm{a}}$ & $87.41^{\mathrm{a}}$ & 2.04 \\
\hline
\end{tabular}

Means within a row having different superscripts differ $(\mathrm{p}<0.01)$ by the Tukey test.

Table 4 - Coefficients of standardized ileal digestibility of amino acids from meat and bone meal using chromic oxide $\left(\mathrm{Cr}_{2} \mathrm{O}_{3}\right)$, acid insoluble ash (AIA), cellulose and lignin as markers.

\begin{tabular}{lccccc}
\hline Amino Acids & $\mathrm{Cr}_{2} \mathrm{O}_{3}$ & AIA & Cellulose & Lignin & CV (\%) \\
\hline Lysine & $76.08^{\mathrm{b}}$ & $81.87^{\mathrm{a}}$ & $85.45^{\mathrm{a}}$ & $86.23^{\mathrm{a}}$ & 2.30 \\
Methionine & $86.39^{\mathrm{c}}$ & $89.73^{\mathrm{b}}$ & $91.79^{\mathrm{ab}}$ & $92.48^{\mathrm{a}}$ & 1.16 \\
Threonine & $83.07^{\mathrm{c}}$ & $87.14^{\mathrm{b}}$ & $90.04^{\mathrm{ab}}$ & $90.91^{\mathrm{a}}$ & 1.69 \\
Arginine & $88.68^{\mathrm{b}}$ & $91.45^{\mathrm{a}}$ & $93.02^{\mathrm{a}}$ & $93.49^{\mathrm{a}}$ & 1.02 \\
Valine & $83.93^{\mathrm{c}}$ & $87.75^{\mathrm{b}}$ & $90.50^{\mathrm{ab}}$ & $91.27^{\mathrm{a}}$ & 1.59 \\
Isoleucine & $83.32^{\mathrm{c}}$ & $87.28^{\mathrm{b}}$ & $90.11^{\mathrm{ab}}$ & $90.87^{\mathrm{a}}$ & 1.66 \\
Leucine & $84.64^{\mathrm{c}}$ & $88.36^{\mathrm{b}}$ & $90.74^{\mathrm{ab}}$ & $91.46^{\mathrm{a}}$ & 1.46 \\
Histidine & $88.18^{\mathrm{c}}$ & $90.92^{\mathrm{b}}$ & $92.81^{\mathrm{ab}}$ & $93.34^{\mathrm{a}}$ & 1.09 \\
Phenylalanine & $85.82^{\mathrm{c}}$ & $89.21^{\mathrm{b}}$ & $91.50^{\mathrm{ab}}$ & $92.16^{\mathrm{a}}$ & 1.35 \\
Cystine & $51.20^{\mathrm{c}}$ & $63.06^{\mathrm{b}}$ & $70.54^{\mathrm{ab}}$ & $72.68^{\mathrm{a}}$ & 6.46 \\
Alanine & $89.35^{\mathrm{c}}$ & $92.09^{\mathrm{b}}$ & $93.69^{\mathrm{ab}}$ & $94.28^{\mathrm{a}}$ & 0.91 \\
Aspartic acid & $82.88^{\mathrm{c}}$ & $87.02^{\mathrm{b}}$ & $89.66^{\mathrm{ab}}$ & $90.44^{\mathrm{a}}$ & 1.65 \\
Glutamic acid & $85.94^{\mathrm{c}}$ & $89.34^{\mathrm{b}}$ & $91.41^{\mathrm{ab}}$ & $92.06^{\mathrm{a}}$ & 1.30 \\
Glycine & $92.70^{\mathrm{c}}$ & $94.51^{\mathrm{b}}$ & $95.62^{\mathrm{ab}}$ & $96.07^{\mathrm{a}}$ & 0.72 \\
Serine & $82.74^{\mathrm{c}}$ & $86.82^{\mathrm{b}}$ & $89.48^{\mathrm{ab}}$ & $90.25^{\mathrm{a}}$ & 1.65 \\
Tyrosine & $80.07^{\mathrm{c}}$ & $84.85^{\mathrm{b}}$ & $87.99^{\mathrm{ab}}$ & $88.83^{\mathrm{a}}$ & 2.01 \\
\hline
\end{tabular}

Means within a row having different superscripts differ $(\mathrm{p}<0.01)$ by Tukey test. 
Although there are questions about the recovery of chromic oxide in ileal digesta of swine, in the present study the standardized ileal digestibilities of amino acids were more consistent compared to those found in the literature, when the chromic oxide was used as a external marker compared with the acid insoluble ash naturally occurring in the experimental diet, as for the lignin and cellulose inserted in the form of rice hull.

The cellulose, despite not undergo fermentative action, did not shows good results, and according to Marais (2000) the indigestible fiber in acid detergent, when used as a marker, shows better results than the cellulose for some species. These authors reported that although pigs do not have enzymes capable of degrading phenolic polymers, associated with the fact that the lignin has a complex structure, and chemical properties that may vary depending on the plant, it has been noticed inconsistency in the recovery of lignin in the faeces (MARAIS, 2000).

Evaluating the chromic oxide and acid-insoluble ash as external markers, Van Leeuwen et al. (1996) observed no differences between the coefficients of apparent ileal digestibility of dry matter and crude protein of the meat and bone meal. However, the authors included $10 \mathrm{~g} / \mathrm{kg}$ of diatomaceus shell powder (source of acidinsoluble ash) in the diet and, in this study, was evaluated the acid-insoluble ash naturally found in the diets (internal marker) what, in parts, may explain the differences obtained by using chromic oxide or acidinsoluble ash as markers, since the relationship between the content of amino acids:acid-insoluble ash may not be representative of the total flux of digesta in the terminal ileum.

The low concentration of acid-insoluble ash and the simultaneous use of chromic oxide in the diets may have influenced the ileal digestibility of amino acids obtained. According to Piaggio et al. (1991), acceptable results cannot be obtained when a low concentration of acid-insoluble ash is used in the feed or in cases of contamination by sand, which is difficult to eliminate interference, as well as the simultaneous use of external markers may compromise the use of acid insoluble ash as a marker.

The differences observed in the ileal digestibility of amino acids resulted in a great variation in the amount of digestible amino acids in the meat and bone meal (Table 5). These variations can lead to a formulation of diets that do not meet, or exceed, the amino acids requirements for pigs in the different production stages, which can increase production costs.

\section{CONCLUSIONS}

The chromic oxide used as a external marker, to determine the coefficients of apparent and standardized ileal digestibility of the amino acids of the meat and bone meal, is most appropriate than the acid insoluble ash naturally occurring in diets, lignin and cellulose.

\section{REFERENCES}

ASSOCIATION OF OFFICIALANALYTICAL CHEMISTS- AOAC. Official Methods of Analysis of the Association of Analytical Chemists, 18th Ed. Gathersburg, MD, USA, 2005.

BERCHIELLI, T.T;; OLIVEIRA, S.G; GARCIA, A.V. Considerações sobre os principais indicadores utilizados em estudos de nutrição com ruminantes. Arquivos de Ciências Veterinárias e Zoologia da UNIPAR, Umuarama, v.8, n.2, p. 205-211, 2005.

EMPRESA BRASILEIRA DE PESQUISA AGROPECUÁRIA-EMBRAPA. Tabela de composição química e valores energéticos de alimentos para suínos e aves. Concórdia, SC: EMBRAPA/CNPSA, 1991, 97p.

FENTON, T.W.; FENTON, M. An improved procedure for the determination of chromic oxide in feed and feces. Canadian Journal of Animal Science, Ottawa, n.3, v.59, p.631-634, 1979.

\section{ITCF - EUROLYSINE. Ileal digestibility of amino acids} in feedstuffs for pigs, Paris: ITCF, 1995. 53p.

JAGGER, S. et al. Evaluation of inert markers for the determination of ileal and fecal apparent digestibility values in the pig. British Journal of Nutrition, Cambridge, n.3, v.68, p.729-739, 1992.

KAVANAGH, S. et al. A comparison of total collection and marker technique for the measurement of apparent digestibility of diets for growing pigs. Animal Feed Science Technology, Amsterdam, v.89, n.1, p.49-58, 2001.

LIEBLER, E.M.; POHLENZ, J.F.; WHIPP, S.C. Digestive System. In: LEMAN, A.D. et al. Diseases of swine, 7.ed, Iowa: Iowa State University Press, 1992, 12-20. 
MARAIS, J.P. Use of Markers. In: D'MELLO, J.P.F. Farm animal metabolism and nutrition, Wallingford: CABI Publishing, p.255-278, 2000.

MCARTHY, J.F.; AHERNE, F.X.; OKAI, D. Use of HCl insolule ash as an index for determining apparent digestiility with pigs. Canadian Journal of Animal Science, Ottawa, v.54, n.1, p.107-109, 1974.

NATIONAL RESEARCH COUNCIL - NRC. Nutrients requirement of swine. $10 \mathrm{ed}$. Washington DC: National Academic Press, 1998, 189p.

PIAGGIO, L.M. et al. Avaliação das cinzas insolúveis em ácido, fibra detergente ácido indigestível e lignina em detergente ácido indigestível como indicadores internos da digestibilidade. Revista da Sociedade Brasileira de Zootecnia, Viçosa, v.20, n.3, p.306-312, 1991.

POZZA, P.C. et al. Composição química, digestibilidade e predição dos valores energéticos da farinha de carne e ossos para suínos. Acta Scientiarum . Animal Science, Maringá, v.30, n.1, p.33-40, 2008.

ROSTAGNO, H.S. et al. Tabelas brasileiras para aves e suínos: composição de alimentos e exigências nutricionais, 3.ed. Viçosa:UFV, 2011, 252p.
ROSTAGNO, H.S. et al. Tabelas brasileiras para aves e suínos: composição de alimentos e exigências nutricionais, 2.ed. Viçosa:UFV, 2005, 186p.

SAKOMURA, N.K.; ROSTAGNO, H.S. Métodos de pesquisa em nutrição de monogástricos.

Jaboticabal:Funep, 2007, 283p.

SAS INSTITUTE. System for Microsoft Windows: release 8.2. Cary, 2001. 1 CD-ROM

SILVA, D.J.; QUEIROZ, A.C. Análises de alimentos:métodos químicos e biológicos. 3.ed. Viçosa:UFV, 2004. 235p.

VAN LEEUWEN, P. et al. Apparent ileal dry metter and crude protein digestiility of rations fed to pigs and determined with the use of chromic oxide ( $\mathrm{Cr} 2 \mathrm{O} 3)$ and acid-insolule ash as digestive markers. British Journal of Nutrition, Cambridge, v.76, n.4, p.551-562, 1996.

ZEOULA, L.M. et al. Uso de indicadores na determinação da digestibilidade parcial e total em bovinos. Acta Scientiarum. Animal Science, Maringá, v.22, n.1, p.771-777, 2000.

ZHANG, Y.C. et al. Effects of casein and protein-free diets on endogenous amino acid losses in pigs. AsianAustralasian Journal of Animal Science, Seoul, v.15, n.11, p.1634-1638, 2002. 
